\title{
The Leadership of Enterprise Education on Poverty Alleviation and Unemployment in Africa
}

http://doi.org/10.21272/bel.3(4).28-33.2019

\section{Adelino Biague Na Dum}

$\mathrm{PhD}$, Professor, Business Department, London School of Science and Technology, United Kingdom

\section{Benneth C. Nwafor}

$\mathrm{PhD}$, Module leader in Business management, Business Department, London School of Science and Technology, United Kingdom

\begin{abstract}
In this modern world, with the rapid development of technologies and an ever-changing market environment, the leadership of enterprise education could be facing significant uncertainty in Africa. The paper aims to identify solutions that would help to remove fundamental barriers to pave the way to the seamless implementation of enterprise education. The broad aim of this study is to shed light on enterprise education and its impact on poverty and unemployment in Africa. The relevance of leadership of enterprise education is to produce graduates with awareness, mindset, and capability to generate original ideas in response to identified needs. The purpose of this research is to investigate the often-neglected interactions between the leadership of enterprise/entrepreneurship education, poverty alleviation, and unemployment reduction. It analyses a transitional pilot program to test the effect on poverty and unemployment trends. The methodological basis of the study was the analytical and comparative methods, methods of analysis, synthesis and logical generalization. In terms of the methodology that was undertaken, a survey comprising of pre-tested and close-ended questions with self-monitoring capability was distributed to participants. Regression analysis was undertaken to understand the nature and scope of interactions between enterprise education and poverty alleviation. Stratified sampling was also employed to gather undiluted data to ascertain the influence of early education, in particular, enterprise education on youth. The study finds that enterprise education creates a supportive environment for jobs and wealth creation. It facilitates individual as well as national growth and development, and it creates sustained employment and poverty elimination. The paper finds that the youth engagement and empowerment can improve Gross Domestic Product (GDP), arrest social unrest, reduce crime rates, and eliminate economic insecurity. This study can be useful for public authorities in the context of the search for alternative tools to reduce poverty in the country.
\end{abstract}

Keywords: enterprise, leadership, entrepreneurship, security, youth, poverty alleviation, education, unemployment.

JEL Classification: L32, K22, I3, I2, E24.

Cite as: Dum, A.B.N., Nwafor, B.C. (2019). The Leadership of Enterprise Education on Poverty Alleviation and Unemployment in Africa. Business Ethics and Leadership, 3(4), 28-33. http://doi.org/10.21272/bel.3(4).28-33.2019.

(C) The Authors, 2019. This article is published with open access at Sumy State University.

\section{Introduction}

Leadership in enterprise education is substantially more than a buzzword. Indeed, it is essential for enterprise education and its leadership to be incorporated at all levels in light of rapidly shifting geo-economic inclinations, especially as the world is now on the verge of entering a predominantly techno-economic age. Daniel et al. (2016) state that enterprise education tends to develop student's competency to engage in commercial opportunities and adapt to the complex business environment.

In African countries, extreme poverty is a recognized hindrance to socio-economic development. In other words, underdeveloped economies and anti-people policies are holding entire nations back in deprived and uncivilized conditions in terms of socio-economic, political, and developmental growth. This has created a generation of impressionable and frustrated youth who are increasingly recruited to guerilla gangs and militias to contribute towards twisted agendas. Today, many African youth are involved in all manner of 
illegal activities such as armed robbery, murder, human as well as drug trafficking, social disruption, espionage, vandalism, and terrorism.

In the current environment of the African continent, intense poverty is also a major hindrance to growth and innovation. Consequently, entire populations all across Africa are prevented from realizing their indigenous potential. In this context, we see that the African continent is being ravaged by devastating poverty, savage hunger as well as deprivation and life-threatening diseases. On the other hand, simple yet talented African youth are sitting ducks for gangs and cannon fodder for global militias and crime syndicates. They are vulnerable targets for radical extremist groups and cults. There is only one way forward to bring healing and localized agency to the people of Africa: respectable local enterprise. The process of developing enterprise education and its leadership must become a culture improve competency, behavior, and attribute.

The Quality Assurance Agency for Higher Education UK known as QAA (2018) defined Enterprise education as the "process of developing students in a manner that provides them with an enhanced capacity to generate ideas, and the behaviours, attributes, and competencies to make them happen". It has also been discussed that enterprise education and its leadership "extends beyond knowledge acquisition to a wide range of emotional, intellectual, social, cultural and practical underlying factors that can enhance employability prospects as well as be taken further through Entrepreneurship education" (QAA UK, 2018).

\section{Enterprise education and its leadership is essential to the African economy in two broad ways if managed efficiently and consistently:}

$>$ it will help to produce graduates that would continuously meet the needs of the modern world in Africa;

graduates/youths will be able to identify opportunities, shortfalls and could act on them, even if circumstances are changing, they should have an idea to adapt accordingly.

It is of critical importance for global thinkers and decision-makers to draw up comprehensive formal and informal broad range education plans based on full-spectrum socio-economic security. These must have the targeted aim to harmonize wayward youth and to bring them back into the systemic economic apparatus. The interests and energy of youths must be harnessed to propel the economic engine of the African continent. Since time immemorial, education has been instrumental in bringing about tectonic civilizational movements with regard to human development. Thus, today it is of no revelation that education is considered to be on a par with global security across the globe to meet a host of socio-economic, cultural, political, racial, scientific, and technological challenges.

Developmental plans should be highly concentrated in terms of institutionalized facilitation and the stimulation of enterprising African youth in their pursuit of diversified economic streams (see Ogundale, 2007). Enterprise education is enshrined in the principle of self-reliance in the sense that a self-reliance philosophy promotes a cultural shift to perceive new environments for enhanced productivity. This approach fosters enterprising attitudes in the quest for a peaceful and empowered future attainment (Agrogundade, 2011). Osuagwu (2002) states that, in addition, greater economic activity generated by entrepreneurial drive serves to set the foundations for incremental economic growth, employment creation, and sustained reductions in the trade deficit.

People in positions of privilege and power should feel a duty to assimilate budding entrepreneurs into national and regional growth streams to set about a process of uninterrupted collective social elevation (Ariya, 2008). Therefore, to be able to rise above historic grievances, African governments need to make a concerted effort to establish a global consensus as a rite of passage to form comprehensive long-term plans to consolidate communities across Africa. This will enable progressive economic domains to mitigate the catastrophic poverty crisis of recent history. The development of a public entrepreneurial mindset is achieved through enterprise education, training, and orientation. Enterprise education provides individuals with an ability to conceive innovative ideas and convert those ideas into profit-making ventures (Omolayo, 2006).

\section{Theoretical Conceptualization of the Analysis}

(Drucker, 1985) explains that entrepreneurship is the ability to recognize changing trends and respond to these as opportunities. By the same token, Kuratko and Hodgetts (2004) observed that, in order to understand entrepreneurship behaviors a cause and effect equation can be used as follows: $E=F(e)$, where Entrepreneurship (E) is a function of Entrepreneur (e). In the increasingly globalized territory, the essence of enterprise education is to gain skills sets relevant to the sound and profitable interpretation of the current economic course, technological direction, and situation in terms of localized inclusion. As Timmons and 
Business Ethics and Leadership, Volume 3, Issue 4, 2019

ISSN (online) - 2520-6311; ISSN (print) - 2520-6761

Spinelli (2004) concluded, the core of entrepreneurship is creatively destabilizing and destructive to the longestablished yet often outdated order of affairs within the immediate natural environment. This is commensurate to Schumpeter's (1942: 132) famous definition who said that the "function of entrepreneurs is to reform or revolutionize the pattern of production by exploiting... an untried technological possibility". So, three-quarters of a century before entrepreneurship began to be discussed against the background of sustainable development. Schumpeter already highlighted its enormous transformative potential. But its effect on poverty has often been neglected.

\section{Poverty Theory}

Poverty theory is categorized into four positions (Ogborn and Abiniku, 2011):

Conservative: The poor are responsible for their poverty;

Liberal Reformist: Poverty is due to lived experience;

> Radical Structural/Marxist: Poverty is the result of the extractive and exploitative nature of capitalism;

Social Exclusion Theory: Poverty is caused by calculated exclusion, thus, the absence of the participation of certain peoples based on color, caste, creed, sexual orientation, and religion in societal activities.

\section{Literature Review}

Ogundele and Olayemi (2004) argue that young entrepreneurs are the ambassadors of positive socioeconomic change at the grass-roots level. In this sense, entrepreneurship ought to be taught in all educational institutions. With such highly financialized governments the world over in developed countries and given the extent of the global private sector diversifying the very framework of traditional economies towards technological and knowledge-based economies, African nations cannot afford to be left behind in the global competition.

Entrepreneurship education is one way forward for African youth in relation to the acquisition of innovative skills and capacity building as demonstrated by the conclusion of this study. The conceptualization of the idea that education and business are interconnected was studied and postulated by a number of authors such as Charney and Libecap (2000), Lulhje and Franks (2002), and Wiklund and Shephred (2003).

Nigeria's NEEDS - National Economic Empowerment and Development strategy - is a good example of a progressive program. However, Ogundale (2004) calls for a new perspective when it comes to spiritual capitalism, and on that attempts to empower individuals to develop themselves, and their communities under the guiding vision of leadership. The successful implementation of NEEDS demands the coordinated growth and expansion of the private sector. This requires monumental entrepreneurship education and training efforts to drive all stages.

Entrepreneurship is the perfect synergy of two behavioral traits that can be trained and refined. These are entrepreneurial practical attitude and entrepreneurial mental attitude. As Alberti et al., (2004) note, entrepreneurship education is a fluid and dynamic interaction between the objectives of a targeted segment of society and it meets the aims of a range of public and private interest groups through targeted pedagogy and assessment.

Research communities more or less agree that the importance of entrepreneurship education cannot be overstated, yet there is a glaring gap in the development of appropriate entrepreneurship education programs. It has been established in the course of this study that communities and peoples have adequate potential to transform themselves into productive and contributive global citizens when they are qualified with valuable skills and oriented towards the enterprise.

For instance, in Ghana, poverty relief measures were based on entrepreneurialism, yet the initiatives failed because they lacked a sufficient number of well-founded entrepreneurial polytechnic programs required to support those measures. Whereas, In Nigeria, the government has launched micro-systems of apposite infrastructure comprised of polytechnic and vocational schools, training institutions, and apprenticeship centers. These are planned around the Youth Empowerment Scheme (YES), National Poverty Alleviation Program (NAPAP), and Rural Infrastructural Development Scheme (RIDS) which together represent a comprehensive poverty and unemployment reduction project.

This study attempts to contribute to the dialogue around meaningful ways to eradicate the category of absolute poverty, but the researcher found that little attention has been paid to programs of entrepreneurship 
education. The hypothesis of this research is that there is a positive relationship between technical skills and youth empowerment as supported by Afzal, (2012). This author observed that nations must invest in multidimensional entrepreneurial education and must increase their productivity to reduce poverty.

Likewise, Squire (1993) asserted that the poor, especially youth, can be made to break away from poverty by means of entrepreneurship education. This notion is therefore tested in the hypotheses in this research. The study postulates that; there is a crucial necessity to design educational programs which are tailored to address the needs of all segments of society.

Additionally, Omoniyi (2013) described poverty as a form of intimidation to the existence of people in modern times. Indeed, the realization that poverty is one of the greatest tragedies of recent times has prompted the undertaking of this paper in order to examine the interactions between enterprise education and poverty reduction.

\section{Theoretical Postulations}

\section{Hypothesis 1}

There is a direct and positive relationship between enterprise education and incremental poverty alleviation.

\section{Hypothesis 2}

There is a direct and positive relationship between technical skills and youth empowerment.

\section{Methodology}

\section{Study Design and Validity}

This paper apart from exploring theoretical conceptions encompasses empirical observations to study the relationship between entrepreneurship education and poverty alleviation and to investigate the impact of entrepreneurship education on unemployment reduction. The study has utilized a quantitative research design that is argumentative in nature, along with a stratified sampling technique. In addition, Ordinary Least Square (OLS), and regression analysis have been used to test whether the hypotheses can be accepted or rejected.

\section{Research Approach}

This study has applied a stratified sampling technique to select 250 participants from Nigeria from a preestablished sampling frame based on a target set on the entrepreneurial and apprenticeship segment of African society.

\section{Research Method}

It was the rationale of the researcher to design a questionnaire immersed in a sound factual and argumentative manner that would result in empirical data mining, which is a pre-requisite for hypotheses testing.

The questionnaire was formulated in two parts. The first part served to gather primary information on age, sex, qualifications, professional status, and marital status. The second part put forward sixteen questions to evaluate the impact of entrepreneurship education on the efforts of poverty alleviation and unemployment reduction. The questionnaire employed a Likert scale to appraise the respondents' agreements with a range of statements.

\section{Subject Data}

Table 1. Demographic classification

\begin{tabular}{|c|c|c|c|c|c|c|c|c|}
\hline $\begin{array}{c}\text { Dep. } \\
\text { Variables }\end{array}$ & $\begin{array}{c}\text { Total } \\
\text { Respondents }\end{array}$ & Entrepreneurs & Apprenticeships & Males & Females & $\begin{array}{c}\text { Age } \\
\text { Bracket }\end{array}$ & $\begin{array}{c}\text { Mean } \\
\text { Age }\end{array}$ & Qualifications \\
\hline $\begin{array}{c}\text { Cons. } \\
\text { Variables }\end{array}$ & 250 & 148 & 102 & 161 & 89 & $24-45$ & 36 & $\begin{array}{l}\text { Higher } \\
\text { secondary }\end{array}$ \\
\hline
\end{tabular}

Source: Elaborated by the authors

This investigator used the Ordinary Least Square (OLS) method to perform hypothesis testing and regression analysis. 


\section{Hypothesis Testing}

H1: There is a direct relationship between entrepreneurship education and incremental poverty alleviation. Equation tested: $\mathrm{Y}=\mathrm{b}_{0}+\mathrm{b}_{1} \mathrm{X}_{1}+\mathrm{b}_{2} \mathrm{X}_{2}$

Table 2. Summary of regression analysis

\begin{tabular}{|l|c|c|c|c|c|c|c|c|}
\hline $\begin{array}{l}\text { Dep. Variable } \\
\text { Entrepreneurship Education }\end{array}$ & $\begin{array}{c}\text { Co-efficient of } \\
\text { Determination }\end{array}$ & T-value & $\begin{array}{c}\text { Std. } \\
\text { Error }\end{array}$ & $\mathbf{R}$ & $\mathbf{R}^{\mathbf{2}}$ & $\mathbf{R}^{2}$ & F-ratio & Sig. \\
\hline Constant Poverty Alleviation & 12.423 & 6.700 & 0.026 & 0.686 & 0.640 & 0.622 & 21.604 & 0.00 \\
& 3.413 & 5.903 & & & & \\
\hline
\end{tabular}

Source: Elaborated by the authors

The result is indicative of the fact that entrepreneurship education is directly related to poverty alleviation. This corroborates the hypothesis that enterprise education culminates into self-reliance/sufficiency, thus, leading to incremental poverty alleviation. The table depicts that the ratio which identifies a direct relationship is 0.686 percent. The coefficient of determination $\left(\mathrm{R}^{2}\right)$ explains the standard presentation score of 60.40 percent in poverty alleviation from the contribution of entrepreneurship education. The adjusted $r$ squared $\left(\mathrm{R}^{-}\right)$which elucidates the actual variations in poverty alleviation reveals the variation of 0.622 as against the 0.640 suggested by $\left(\mathrm{R}^{2}\right)$. The standard error of 0.026 proposes that the independent variable (education) is noteworthy in explaining the variation in poverty alleviation. The t-test of significance (5.903) suggests that the existing relationship between entrepreneurship education and poverty alleviation is accurate. The F statistic which illustrates the overall connotation of the model demonstrates that the model is a good indicator because the calculated F-ratio of 21.604 is greater than the table value of 3.92 at $5 \%$ at the level of connotation. The independent variable is a good predictor of the dependent variable.

H2: There is a direct and positive relationship between technical skill and youth empowerment. Equation tested: $\mathrm{Y}=\mathrm{b}_{0}+\mathrm{b}_{1} \mathrm{X}_{1}+\mathrm{b}_{2} \mathrm{X}_{2}$

Table 3. Summary of regression analysis

\begin{tabular}{|l|c|c|c|c|c|c|c|c|}
\hline Dep. Variable Technical Skill & $\begin{array}{c}\text { Co-efficient of } \\
\text { Determination }\end{array}$ & T-value & $\begin{array}{c}\text { Std. } \\
\text { Error }\end{array}$ & $\mathbf{R}$ & $\mathbf{R}^{2}$ & $\mathbf{R}^{2}$ & F ratio & Sig. \\
\hline Constant Youth Empowerment & 8.321 & 6.430 & 0.014 & 0.690 & 0.678 & 0.613 & 19.402 & 0.000 \\
& 2.016 & 5.868 & & & & \\
\hline
\end{tabular}

Source: Elaborated by the authors

As shown in the above results, youth empowerment requires a significant degree of technical assistance. Table 3 shows that the best part of youth believe that technologies and technical knowledge have empowered and enabled them. The magnitude of the coefficient of determination $\left(\mathrm{R}^{2}\right)$ which is 0.678 specifies a standard relationship between the two variables. The relationship is noteworthy, in light of the value of the coefficient of determination and the t- statistics of 5.868. This suggests that a large percentage of technical skills are attributed to youth empowerment. However, the table does not illustrate the adequacy of the technical skills contrasted with entrepreneurship education. Although, entrepreneurship education translates into incremental unemployment reduction as youth begin to explore self-employment and employment/job creation for peers.

\section{Conclusion}

This study examined entrepreneurship education as a viable form of functional education suitable to address the needs of the youth of the African continent. It is proven beyond doubt that entrepreneurship education and training from the elementary stage set the foundation for the early development and empowerment of youth in order to stimulate a continued process of poverty alleviation. Entrepreneurship is the key which unlocks individuals, the state, national, continental, and international wealth creation potential. Entrepreneurship education, when implemented and supported in a satisfactory fashion can resolve global issues such as underemployment, unemployment, poverty, social backwardness, and war.

\section{Recommendations}

Policy makers need to address the overwhelming growth gap by instituting entrepreneurship education as a long-term remedy.

Entrepreneurship education is critical for the achievement of poverty elimination, self-sufficiency, and security. 
Business Ethics and Leadership, Volume 3, Issue 4, 2019

ISSN (online) - 2520-6311; ISSN (print) - 2520-6761

Elites within the private sector should cultivate young grass-roots entrepreneurial initiatives so as to fulfill their social and moral obligations.

Entrepreneurship education must be introduced in schools as a priority

Federal as well as local governments must set aside state funding exclusively for entrepreneurship education, training, and scholarships.

As a solution to prevent the migration of entrepreneurs, African countries' governments ought to supply energy, reasonable healthcare services, clean drinking water, and appropriate infrastructure at a reduced cost.

The board of entrepreneurs must actively contribute towards entrepreneurship, poverty alleviation, and welfare research to promote technological advancement.

\section{References}

1. Afzal, M., Ehsan, M. M., Ishrat, B., Kafeel, S., Hina, F. (2012). Relationship among Education, Poverty, and Economics Growth in Pakistan. Journal of Elementary Education, 22(1), 23-45. ISSN-Online: 22271090; Print: 1991-8100.

2. Alberti, F., Sciscia, S., \& Poli, A. (2004). Entrepreneurship Education: Notes on an ongoing debate. Proceedings of the 14th Annual International Entrepreneur Conference, University of Napoli Federico 11, Italy.

3. Ariyo, D. (2008). Small firms are the backbone of the Nigerian economy. Page 11.

4. Arogundade, B.B. (2011). Entrepreneurship Education: An Imperative for Sustainable Development in Nigeria. Journal of Emerging Trends in Educational Research and PolicyStudies (JETERAPS), 2(1), 2629. ISSN: 2141-6990.

5. Charney, A., \& Libecap, D.B. (2000). The Impact of Entrepreneurship Education: An Evaluation of the Berger Entrepreneurship Program at the University of Arizona, 1985-1999. Kansas City, MI: The Kauffman Center for Entrepreneurial Leadership. Available at: http://citeseerx.ist.psu.edu/viewdoc/download?doi=10.1.1.584.9846\&rep=rep1\&type=pdf.

6. Daniel, M., Rainer, H., Norbert, K., Birgit, W. (2016) The impact of entrepreneurship education on the entrepreneurial intention of students in science and engineering versus business studies university programs. Technol. Forecast.soc.104 172-179.10.1016/j.techfore.2015.11.006 [google scholar], accessed on $16 / 11 / 2019$.

7. Drucker, P.F. (1985). Innovation and Entrepreneurship: Practice and Principles. New York: Harper and Row, 277 pp.

8. Kuratko, D.F., \& Hodgetts, R.M. (2004). Entrepreneurship: Theory, Process, and Practice. Mason, OH; South-Western Publishers.

9. Ogundele, O.J.K. (2007). Introduction to Entrepreneurship Development, Corporate Governance, and Small Business Management. Lagos: Molofin Nominees.

10.Omolayo, B. (2006). Entrepreneurship in Theory and Practice. F. Omotosho, T.K.O. Aluko, O.I. Wale Awe.

11.Ogboru, I., \& Abiniku, A. C. (2011). The Impact of corruption on poverty reduction efforts in Nigeria. Page 3. Paper accessed online.

12.Ogundele, O.J.K., \& Olayemi, O.O. (2004). Entrepreneurial Education and Social Economic Reconstruction. Nigeria Journal of Curriculum and Institution, 12(1), 12. Paper accessed online.

13.Ogundele, O.J.K. (2004). Wealth Creation through the Development of Indigenous Technology. 12 National Conference Environments and Behavior of Association of Nigeria, University of Agriculture, Abeokuta. 24-26.

14.Omoniyi, M. B. I. (2013). The Role of Education in Poverty Alleviation and Economic Development: a theoretical perspective and counselling implications. British Journal of Arts, and Social Sciences, 15(2), 2046-9578. ISSN: 2046-9578.

15.Osuagwu, L. (2002). Entrepreneurship in a Developing Economy: Empirical evidence from Nigeria Business Organizations. International Journal of Entrepreneurship, 6, 19-32. ISSN 1099-9264.

16.QAA (2018). Enterprise and entrepreneurship education: Guidance for UK Higher Education providers. Available at: https://www.qaa.ac.uk/docs/qaas/enhancement-and-development/enterprise-andentrpreneurship-education-2018.pdf?sfvrsn=15f1f981_8.

17. Schumpeter, J.A. (1942). Capitalism, Socialism and Democracy. $3^{\text {rd }}$ edition, London: George Allen and Unwin, $1976 . \quad$ Available at: online.org/files/etranslation/original/Schumpeter,\%20Capitalism,\%20Socialism\%20and\%20Democracy.pdf.

18.Squire, L. (1993). Fighting Poverty. American Economic Review, 83(2), 377-382. Available at: https://www.jstor.org/stable/2117694?seq=1.

19.Timmons, J.A., \& Spinelli, S. (2004). New Venture Creation: Entrepreneurship for the 21st Century. Boston: McGraw Hill Irwin.

20.Wiklund, J., \& Shepherd, D. (2003). Knowledge-based Resources, Entrepreneurial Orientation of Small and Medium-sized Businesses. Strategic Management Journal, 24(13), 1307-1314. DOI: $10.1002 /$ smj.360. 